\title{
Adherence to Antihypertensive Medication in Patients with Hypertension in Indonesia
}

\author{
Tania, ${ }^{1}$ Vycke Yunivita, ${ }^{2}$ Afiatin $^{3}$ \\ ${ }^{1}$ Faculty of Medicine Universitas Padjadjaran, Indonesia \\ ${ }^{2}$ Department of Biomedical Science Faculty of Medicine Universitas Padjadjaran, Indonesia \\ ${ }^{3}$ Department of Internal Medicine Faculty of Medicine Universitas Padjadjaran/Dr. Hasan Sadikin Hospital \\ Bandung, Indonesia
}

Abstract Objective: Adherence to medication is crucial for hypertension patients in order to control and prevent complications. This study aimed to describe the adherence to antihypertensive drugs among patients with hypertension in Bandung District, West Java, Indonesia.

Methods: This was a cross-sectional observational study on patients with hypertension in the work area of Cileunyi Public Health Center (PHC), Bandung District, West Java, Indonesia. The inclusion criteria used were patients with hypertension who were prescribed an antihypertensive drug by a physician, above 18 years old, and had been using an antihypertensive medication for at least two months before the study. Data were obtained through interviews during the month of July to August 2018 using a modified MMAS-8 questionnaire of the Morisky Medication Adherence Scale (MMAS8), which includes Likert-type scale questions. Data collected were then analyzed using the Rasch Model, and the mean logit person was used as a cut off between adherence and non-adherence categories.

Results: A total of 75 patients with hypertension were recruited. The prevalence of adherence to medication was $59 \%$. Most patients who adhered to the medication were $\geq 55$ years old (31\%), female (59\%), had been diagnosed with hypertension for $<5$ years (31\%), and received support from family/social environment (40\%).

Conclusions: Many factors support the adherence to antihypertensive medication, including age, gender, time of hypertension diagnosis, and support from family or social environment. The adherence to antihypertensive

Received:

January 9, 2019 medication among patients with hypertension visited Cileunyi Primary

Revised:

September 30, 2019

Health Care, Bandung District, West Java, Indonesia is good.

Accepted:

October 19, 2019

Keywords: Adherence, antihypertensive medication, hypertension, Indonesia, primary health care

pISSN: 2302-1381; eISSN: 2338-4506; http://doi.org/10.15850/ijihs.v7n2.1588

IJIHS. 2019;7(2):74-80

\section{Introduction}

Primary hypertension is a global health problem that affects most countries in the world. Hypertension is defined as a condition with increased systolic blood pressure (SBP) above $130 \mathrm{mmHg}$ and increased

Correspondence:

Vycke Yunivita,

Department of Biomedical Science, Faculty of Medicine

Universitas Padjadjaran

e-mail: v.yunivita@unpad.ac.id diastolic blood pressure (DBP) of more than $80 \mathrm{mmHg} .{ }^{1} \mathrm{An}$ increase of about $20 \mathrm{~mm} \mathrm{Hg}$ in SBP and $10 \mathrm{~mm} \mathrm{Hg}$ in DBP increases the risk of death from vascular disease, stroke, and other vascular diseases. Higher SBP and DBP were associated with increased risk of several vascular diseases, such as cardiovascular diseases (CVDs), in more than one million adult patients aged $>30$ years worldwide. ${ }^{1}$ Results of the Indonesian Basic Health Survey (IBHS) 2018 show that the prevalence of hypertension in Indonesia for the population above 18 years old is $8.4 \%$ based on the selfreported answer from the respondents who 
stated that they had been diagnosed to be suffering from hypertension by a physician. Meanwhile, the same survey also reported that the prevalence of hypertension is $34.1 \%$ based on blood pressure measurement performed during the survey. A higher prevalence of hypertension is seen among women when compared to men. ${ }^{2}$

In West Java Province, the West Java Provincial Health Office reported that, in 2016, there were 790,382 hypertension cases in the province with 118,751 of them were found in Bandung District, which was the highest compared to the number found in other districts in the province. ${ }^{3}$ Cileunyi Sub-District is a peri-urban area of Bandung District that has been transforming from a rural area to an urban area. Cileunyi Sub-District is an area that has access to several other districts: Tasikmalaya and Garut District in the south and Sumedang and Cirebon District in the east. It is also directly adjacent to Jatinangor SubDistrict of Sumedang District. The fact that this subdistrict is highly accessible from many other areas making it one of the main destinations of migration, resulting in increased population and land-use shift from agricultural land into residential and commercial areas. ${ }^{4}$ This rural-to-urban shift does not only affect the land use and infrastructure development but also affects the lifestyle and culture of the community. Changes in the lifestyle also include changes in the diet that tend to move towards instant food or fast food consumption. The higher tendency to use motorized vehicles has also reduced walking activities among people. ${ }^{5}$ These two changes create risk factors for non-communicable diseases. Consequently, this leads to an increase in the incidence and mortality caused by non-communicable diseases, including hypertension, in Cileunyi District. ${ }^{6}$

Several factors affect a person's adherence. First, the socioeconomic factors that include low education level and limited motivation. The second is the health service factors that include the uneven distribution of health facilities, inadequate number of health workers, limited consultation time, lack of communication with patients, and lack of health worker's knowledge in treating chronic diseases. The third factor is the conditionrelated factors, for example, the severity of disease, complications, and prognosis. The fourth factor is therapy-related factors, such as complex therapy, duration of treatment, history of previous therapy errors mistake, and drug side effects. The last factor is the patient-related factors that include the level of knowledge and confidence, motivation in treatment, absence of symptoms, frustration caused by the disease, anxiety towards drug side-effects, and confidence to recover. The five factors above may reduce adherence to medication in almost every country, including Indonesia. ${ }^{7}$ Adherence to medication can be interpreted as a patient's behavior in abiding to doctor's recommendations in accordance with medical demands. The low adherence is the main cause of treatment failure, especially in the treatment of chronic diseases such as hypertension treatment. ${ }^{8}$

This study aimed to determine the level of adherence to antihypertensive drugs among hypertension patients visiting a public health center in Bandung District, West Java, Indonesia.

\section{Methods}

This is a cross-sectional quantitative descriptive study on adherence to medication for hypertensive patients. Data were obtained by interview using the Morisky Medication Adherence Scale-8 (MMAS-8) questionnaire, a structured self-report indicator of drugtaking behavior, which is commonly used and has been validated for antihypertensive drugs in different cultures. ${ }^{9}$ The study was performed from July to August 2018 in the working area of Cileunyi Primary Health Care (PHC), Bandung District, West Java and has been approved by the Health Research Ethics Committee, Faculty of Medicine, Universitas Padjadjaran no 847/UN6.KEP/EC/2018.

The subjects in this study were patients with hypertension treated at the Cileunyi PHC $(n=75)$. The inclusion criteria were outpatients aged more than 18, had received hypertension diagnosis from a doctor, consumed antihypertensive agents prescribed by a doctor, duration of treatment minimum of two months, and had given consent to participate in the study. The exclusion criteria were the subjects who bought their own medicine without a doctor's prescription, patients who came to the PHC for the first time, and patients who could not communicate well.

Data collection was carried out by conducting interviews on patient's characteristics and adherence using the MMAS-8 questionnaire that had been tested for validity and reliability. ${ }^{10,11}$ The MMAS questionnaire used in this study contained eight questions with seven dichotomy scale questions and one Likert scale question. 
Data were then analyzed using the Rasch Model on Winstep software 3.73 (Winsteps, USA). Results were represented as a logit person for each person to describe treatment adherence. The adherence level were classified into two categories. The first was the adherence category represented by a logit person value above the mean score and the second category was the non-adherence category, which was represented by a logit person value under the mean score. Respondents characteristics in terms of adherence were processed using the SPSS version 22 (spss.license.unpad.ac.id).

\section{Results}

Seventy-five respondents who suffered from hypertension and visiting the Cileunyi PHC participated in this study. The Wright distribution pattern of respondents and questionnaire items were represented in a Wright's Map (Fig.). The average logit person value based on analysis using the Rasch model was -0.88 . The Wright's Map was then used to determine the adherence level. Fortyfour respondents $(59 \%)$ were included into the adherence category (59\%) and 31 were classified into the non-adherence category $(41 \%)$.

The results exhibited that the majority of the respondents were over 55 years old, female, graduated from elementary school, and unemployed. All respondents were married and consumed only one type of

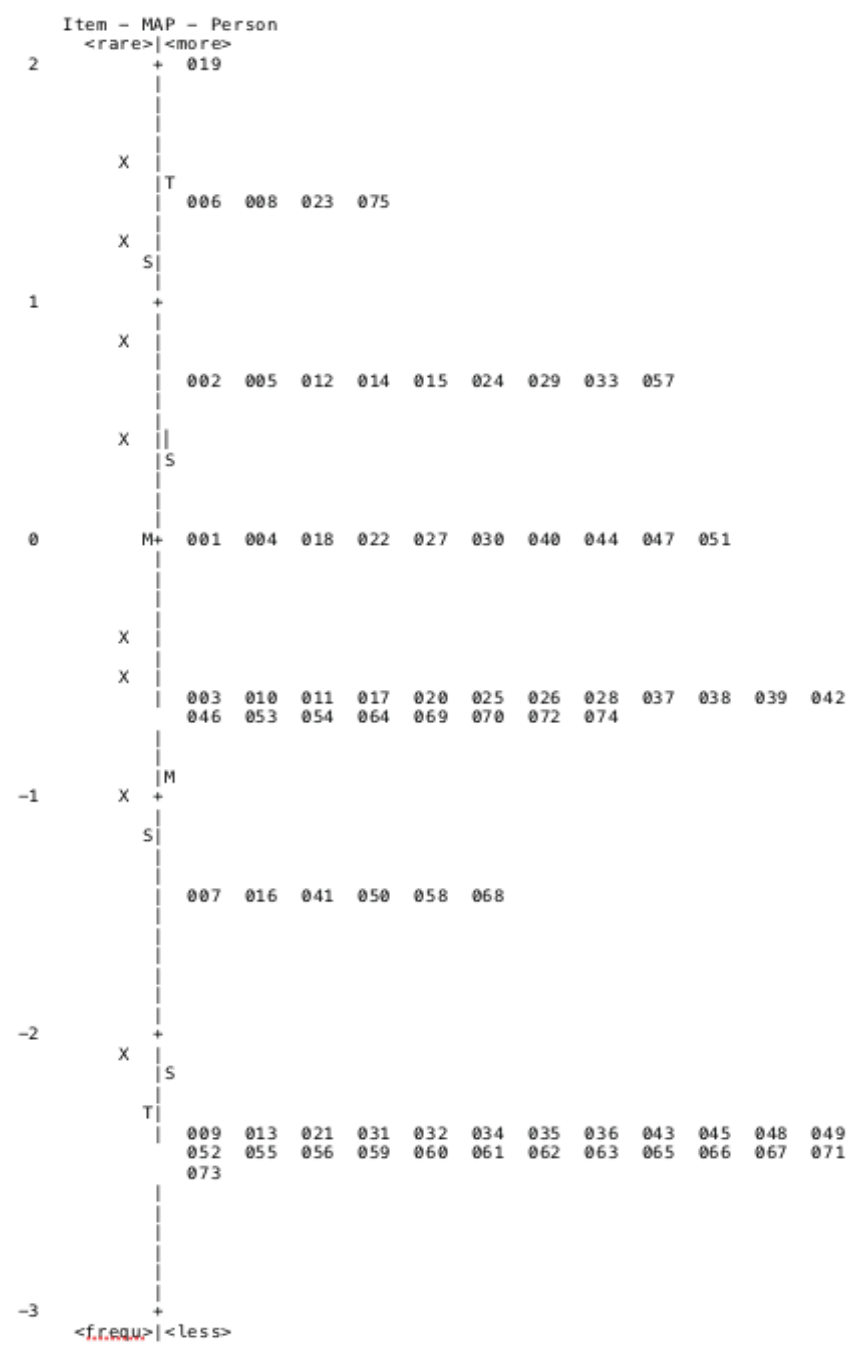

Figure Wright Distribution Pattern of Respondents and Questionnaire Items 


\section{Table Respondent Characteristics by Adherence}

\begin{tabular}{|c|c|c|c|}
\hline Characteristics & $\begin{array}{c}\text { Adherence } \\
\text { n (\%) }\end{array}$ & $\begin{array}{c}\text { Non-adherence } \\
\text { n (\%) }\end{array}$ & $\begin{array}{c}\text { Total (\%) } \\
n=75\end{array}$ \\
\hline \multicolumn{4}{|l|}{ Age } \\
\hline$\leq 55$ years & $21(60 \%)$ & $14(40 \%)$ & $35(47 \%)$ \\
\hline$>55$ years & $23(57 \%)$ & $17(43 \%)$ & $40(53 \%)$ \\
\hline \multicolumn{4}{|l|}{ Gender } \\
\hline Male & $7(47 \%)$ & $8(53 \%)$ & $15(20 \%)$ \\
\hline Female & $37(62 \%)$ & $23(38 \%)$ & $60(80 \%)$ \\
\hline \multicolumn{4}{|l|}{ Education } \\
\hline No school & $2(100 \%)$ & $0(0 \%)$ & $2(3 \%)$ \\
\hline Elementary school & $29(63 \%)$ & $17(37 \%)$ & $46(61 \%)$ \\
\hline Junior high school & $6(46 \%)$ & 7 (54\%) & $13(17 \%)$ \\
\hline Senior high school & $5(42 \%)$ & $7(58 \%)$ & $12(16 \%)$ \\
\hline College & $2(100 \%)$ & $0(0 \%)$ & $2(3 \%)$ \\
\hline \multicolumn{4}{|l|}{ Occupation } \\
\hline Employment & $8(67 \%)$ & $4(33 \%)$ & $12(16 \%)$ \\
\hline Unemployment & $36(57 \%)$ & $27(43 \%)$ & $63(84 \%)$ \\
\hline \multicolumn{4}{|l|}{ Marital status } \\
\hline Single & $0(0 \%)$ & $0(0 \%)$ & $0(0 \%)$ \\
\hline Married & $44(59 \%)$ & $31(41 \%)$ & $75(100 \%)$ \\
\hline \multicolumn{4}{|l|}{ Duration of being aware of hypertension status } \\
\hline$\leq 5$ years & $23(59 \%)$ & $16(41 \%)$ & $39(52 \%)$ \\
\hline$>5$ years & $21(58 \%)$ & $15(42 \%)$ & $36(48 \%)$ \\
\hline \multicolumn{4}{|l|}{ Number of drug type } \\
\hline 1 & $44(59 \%)$ & $31(41 \%)$ & $75(100 \%)$ \\
\hline$>1$ & $0(0 \%)$ & $0(0 \%)$ & $0(0 \%)$ \\
\hline \multicolumn{4}{|l|}{ Drug type } \\
\hline ACE Inhibitor & $23(70 \%)$ & $10(30 \%)$ & $33(44 \%)$ \\
\hline Calcium channel blocker & $21(50 \%)$ & $21(50 \%)$ & $42(56 \%)$ \\
\hline Other & $0(0 \%)$ & $0(0 \%)$ & $0(0 \%)$ \\
\hline \multicolumn{4}{|l|}{ Income (Indonesian Rupiah/IDR) } \\
\hline$<1,500,000$ & $41(57 \%)$ & $31(43 \%)$ & $72(96 \%)$ \\
\hline $1,500,000-2.500 .000$ & $2(100 \%)$ & $0(0 \%)$ & $2(3 \%)$ \\
\hline $2,500,000-3,500,000$ & $1(100 \%)$ & $0(0 \%)$ & $1(1 \%)$ \\
\hline $3,500,000$ & $0(0 \%)$ & $0(0 \%)$ & $0(0 \%)$ \\
\hline \multicolumn{4}{|l|}{ Cost coverage } \\
\hline Out-of-Pocket & 17 (81\%) & $4(19 \%)$ & $21(28 \%)$ \\
\hline Borne by other parties (insurance, family, etc.) & $27(50 \%)$ & $27(50 \%)$ & $54(72 \%)$ \\
\hline \multicolumn{4}{|l|}{ Support from family/social environment } \\
\hline Yes & $30(64 \%)$ & $17(36 \%)$ & $47(63 \%)$ \\
\hline No & $14(50 \%)$ & $14(50 \%)$ & $28(37 \%)$ \\
\hline
\end{tabular}


drug. Most respondents had known that they had hypertension for less than 5 years, took Calcium Channel Blocker drugs, had a monthly income of less than Indonesian Rupiahs (IDR) $1,500,000,00$, had the treatment costs borne by other parties, and received good support and motivation from family or social environment.

The number of respondents in the age group $>55$ years who were in the non-adherence category was higher (Table 2). Women showed a higher percentage of adherence than men and most of the non-adherence respondents were graduated from elementary school. Respondents who were employed were most likely to be in the adherence group than those who were unemployed. Married respondents tended to be adherent. When adherence was assessed from the perspective on how long the patients had known about their hypertension status, adherence was found to be more prevalent in the group who was were aware that they were hypertensive for less than 5 years. All respondents took one type of drug and mostly adhered to the treatment. In terms of the type of drug consumed, respondents in the non-adherence group were more likely to take Calcium Channel Blocker. Most respondents, who had an income less than IDR 1,500,000, were adherent. Respondents who use their own money tended to adhere to the treatment. Family and social support also influenced the adherence with a higher percentage of respondents with good family and social supports adhered to the treatment.

\section{Discussion}

Patients with hypertension visited the Cileunyi PHC were analyzed based on several characteristics. When the age was crossexamined with adherence, it was revealed that more patients who were $>55$ years old were in the non-adherence group compared to the younger counterpart ( $\leq 55$ years old). This is in accordance with the results of the IBHR 2018 stating that the most common disease in the elderly is hypertension (57.6\%). ${ }^{2}$ It is expected that when a person is getting older, his or her incidence of having a high blood pressure increases. This is because the blood vessel structure and function change with aging, which in turns affect body hemodynamics or blood pressure regulation. These changes include the, including loss of connective tissue elasticity, decreased relaxation of vascular smooth muscle, and atherosclerosis. ${ }^{12}$ As people get older, the organ system also experiences declined function, including the limbic system which controls memories. ${ }^{13}$ As a result, patients who are $>55$ years may have a lower level of adherence than patients who are $\leq 55$ years due to lower memory capacity.

Sixty women $(80 \%)$ with hypertension participated as the respondents, which is far greater than men $(n=15,20 \%)$. This is consistent with the results of the IBHR 2018 that demonstrated a higher prevalence of hypertension among women in Indonesia when compared to men. ${ }^{2}$ Women experience menopause, which involves hormonal changes resulting in a decreased ratio of estrogen to androgen hormones that leads to higher renin release which then triggers an increase in blood pressure.14 Nevertheless, women have a higher level of adherence than men, which is similar to the finding of a previous study that reported female respondents to be more concerned about their health due to the higher availability of time and opportunities to visit the PHC than men. ${ }^{15}$

The respondents of this study were predominantly graduated from elementary school $(n=46,(61 \%)$ with varied adherence level. Thus, education seems to not affecting patient's adherence. A person with a higher education level does not necessarily have better adherence and vice versa. This is because respondents' knowledge is not only obtained through formal education but also from experience or other information media, such as television, newspaper, radio, and the internet. The knowledge of treatment adherence could also be gained from the communication between patients and their healthcare provider. ${ }^{16}$

Based on the occupational group, most respondents were unemployed. The reason for the high rates of hypertension among unemployed patients is that the physical activities of unemployed patients are less than those who work. Physical activities can facilitate blood flow while the lack of physical activities can increase the risk of obesity and hypertension. ${ }^{17}$ Respondents who work have higher adherence than those who do not work. On the contrary, a previous study stated that higher adherence is found among unemployed patients. Their argument is that these patients have more time at home so they have more opportunities to take their medication regularly. ${ }^{18}$ All hypertensive patients in the Cileunyi PHC were married. No previous report has explained the relation between marital status and hypertension, but an assumption can be made that because hypertension is more common in old age and 
one tends to get married at the age of 20 years old or older, more married patients experience hypertension. Patients who are married have more family support for taking the medicine by reminding to take the medicine as prescribed. Hence, they have more controlled hypertension. ${ }^{19}$

Most respondents of this study have known about their hypertension status for less than 5 years and all of the respondents only took one type of drug. A previous study stated that patients with one drug regimen have a higher adherence level than patients with multiple drug regimens. ${ }^{8}$ This may be because patients who consume multiple drugs tend to forget to take their medicine and finally get tired of it, resulting in a lower adherence.

Based on the type of drug consumed, two classes of antihypertensive drugs were used by the respndents, namely ACE inhibitors (Captopril) and calcium channel blockers (Amlodipine). The number of respondents who took Captopril was less than those who took Amlodipine, albeit with a higher level of adherence. This is in contrast with the adherence level is a previous study showing that patients who take Amlodipine are more adherent that those who take Captopril. The researchers assumed that it may be due to the most common side effect of Captopril, which is coughing, that is less tolerable and may interfere with patients' daily activities. This is also because patients only need to take Amlodipine once a day. ${ }^{20}$

Out of seventy-five respondents in the Cileunyi PHC, the majority had a monthly income below IDR $1,500,000$. There were two respondents whose income was between IDR 1,500,000 and IDR 2,500,000 and one respondent had an income of between IDR $2,500,000$ and IDR 3,500,000. No statistically significant difference is found regarding income.$^{18}$ However, this study cannot conclude the relationship due to limited sample size and possible bias.

Respondents who bear their own costs have higher adherence than respondents whose cost was borne by other parties. Most of the respondents have their medical expenses covered by other parties such as by the National Health Insurance. This situation is the opposite of the findings of a previous study that shows a lower adherence level among those who pay for their own cost. Other study reported that with the availability of health insurance, patients can obtain drugs regularly and, thus, more adherent than those who are not covered by insurance. ${ }^{18}$
This study shows that patients that do not have family/social support have a lower adherence level. The form of support can be a reminder to take the antihypertensive drug from the child or spouse. Moral support from others can also increase patient's selfmotivation and lead to a high adherence level. Adherence to drugs is the most important aspect of a patient's treatment. Good support from the patient's family or social environment is a social factor that can predict adherence. ${ }^{21}$

To summarize, the adherence to treatment is crucial for every patient. It is necessary to control hypertension and prevent complications. The Primary Health Care plays a role in improving patient adherence. Education about the benefit of taking antihypertensive drugs regularly should be provided to patients so they are more aware of their disease and the importance of taking medicine, thus leading to a high adherence level. Education to the patient's family members is also important.

It can be concluded that the majority of the respondents are over 55 years old, female, graduated from elementary school, and unemployed. All respondents are married and take one drug regimen. Most of the respondents have known that they have hypertension for less than 5 years, take Calcium Channel Blocker, have monthly income less than IDR 1,500,000,00, havve the costs borne by other parties, and get good motivational support from family or social environment. Most patients with hypertension in Cileunyi Primary Health Care have good adherence to antihypertensive drugs.

\section{References}

1. Whelton PK, Carey RM, Aronow WS, Casey DE, Collins KJ, Dennison Himmelfarb C, et al. 2017 ACC/AHA/AAPA/ABC/ACPM/AGS/ APhA/ASH/ASPC/NMA/PCNA Guideline for the Prevention, Detection, Evaluation, and Management of High Blood Pressure in Adults: A Report of the American College of Cardiology/ American Heart Association Task Force on Clinical Pr. Hypertension. 2018;71(6):e13-115.

2. Kementerian Kesehatan RI. Hasil Utama Riskesdas 2018. Riset Kesehatan Dasar. Jakarta; 2018.

3. Dinas Kesehatan Provinsi Jawa Barat. Profil Kesehatan di Jawa Barat Tahun 2016. Dinas Kesehatan Jawa Barat. 2017. p. 188-196.

4. Suparman E, Afiatun E, Rusmaya D. Perencanaan Sistem Drainase Berwawasan 
Lingkungan Di Kecamatan Cileunyi Kabupaten Bandung. 2008.

5. Mansur M. Problematika Urbanisasi. Al-Munzir. 2014;7(1):70-82.

6. Handajani A, Roosihermiatie B, Maryani H. Faktor-faktor yang berhubungan dengan pola kematian pada penyakit degeneratif di Indonesia. Bull Heal Syst Res. 2010;13(1):4253.

7. Reach G. A novel conceptual framework for understanding the mechanism of adherence to long term therapies. Patient Prefer Adherence. 2008;2:7-19.

8. Ramli A, Ahmad NS, Paraidathathu T. Medication adherence among hypertensive patients of primary health clinics in Malaysia. Patient Prefer Adherence. 2012;6:613-22.

9. Nasasira B, Ndichu A, Muiru W, Link C, Okello S, Nasasira B, et al. Validity and Reliability of a Self-Reported Measure of Antihypertensive Medication Adherence in Uganda. PLoS One. 2018;11(7):1-11.

10. de Oliveira-Filho AD, Morisky DE, Neves SJF, Costa FA, de Lyra DP. The 8-item Morisky Medication Adherence Scale: Validation of a Brazilian-Portuguese version in hypertensive adults. Res Soc Adm Pharm. 2014;10(3):55461.

11. Alfian SD, Sukandar H, Lestari K, Abdulah R. Medication Adherence Contributes to an Improved Quality of Life in Type 2 Diabetes Mellitus Patients: A Cross-Sectional Study. Diabetes Ther. 2016;7(4):755-64.

12. Fleg JL, Strait J. Age-associated changes in cardiovascular structure and function: A fertile milieu for future disease. Heart Fail Rev. 2012;17(4-5):545-54.

13. St. Jacques PL, Dolcos F, Cabeza R. Effects of aging on functional connectivity of the amygdala for subsequent memory of negative pictures: A network analysis of functional magnetic resonance imaging data. Psychol Sci. 2009;20(1):74-84.

14. Cannoletta M, Cagnacci A. Modification of blood pressure in postmenopausal women: Role of hormone replacement therapy. Int J Womens Health. 2014;6:745-57.

15. Bidmon S, Terlutter R. Gender differences in searching for health information on the internet and the virtual patient-physician relationship in Germany: Exploratory results on how men and women differ and why. J Med Internet Res. 2015;17(6):e156.

16. Schoenthaler A, Chaplin WF, Allegrante JP, Fernandez S, Diaz-Gloster M, Tobin JN, et al. Provider communication effects medication adherence in hypertensive African Americans. Patient Educ Couns. 2009 May;75(2):185-91.

17. Diaz KM, Shimbo D. Physical activity and the prevention of hypertension. Curr Hypertens Rep. 2013;15(6):659-68.

18. Cho S-J, Kim J. Factors associated with nonadherence to antihypertensive medication. Nurs Health Sci. 2014;16(4):461-7.

19. Lewis LM, Askie P, Randleman S, SheltonDunston B. Medication adherence beliefs of community-dwelling hypertensive African Americans. J Cardiovasc Nurs. 2010;25(3):199206.

20. Benowitz NL. Antihypertensive agents. In: Katzung BG, editor. Basic and Clinical Pharmacology. 14th ed. USA: The McGraw-Hill Companies; 2017. p. 173-276.

21. Lewis LM. Factors associated with medication adherence in hypertensive blacks: A review of the literature. J Cardiovasc Nurs. 2012;27(3):208-19. 